\title{
Percepções sobre o Turismo em Áreas Rurais: limitações e possibilidades na APA Caverna do Maroaga, Presidente Figueiredo/AM
}

\author{
João Rodrigo Leitão dos Reis \\ Julio César Rodríguez Tello \\ Christina Fischerc
}

\begin{abstract}
Resumo
O turismo em unidades de conservação é uma alternativa para sua sustentabilidade financeira e ambiental, com envolvimento da população local. No intuito de conhecer esse processo na área de proteção ambiental (APA) Caverna do Maroaga, realizamos uma investigação exploratória em três comunidades do local, analisando a situação atual, as expectativas de melhoria dessa atividade, a percepção, o interesse e a motivação dos comunitários. As informações foram coletadas a partir de 87 entrevistas com adultos da região. Constatandose que o turismo dessas comunidades se direciona aos atrativos naturais, mas sem um uma organização adequada, percebe-se que os comunitários têm interesse e motivação para iniciar uma diretriz de gestão, mas não estão preparados para empreender ou desenvolver programas e desconhecem uma possível oferta de cursos de capacitação necessários para tal. Palavras-chave: Áreas rurais; Turismo; Unidade de conservação.
\end{abstract}

\section{Abstract \\ Perceptions on Tourism in Rural Areas: limitations and possibilities in APA Caverna do Maroaga, Presidente Figueiredo/AM}

Tourism in conservation units is an alternative for their financial and environmental sustainability, involving the local population. To know this process in the environmental protection area (APA - Área de Proteção Ambiental) Caverna do Maroaga, we performed an exploratory investigation in three local communities, analyzing the current situation, the expectations of improvement of this activity, and the awareness, interest, and motivation of the community. Information were collected from 87 interviews with adults of the region. Noting that the tourism of these communities focuses on natural attractions, but without proper organization, we observed that the community is interested and motivated to start a management guideline but is not prepared to undertake or develop programs and are unaware of a possible supply of training courses required for it.

Keywords: Rural areas; Tourism; Conservation unit.

a. Doutorando pelo Programa de Pós-Graduação em Ciências do Ambiente e Sustentabilidade na Amazônia (PPG-Casa) da Universidade Federal do Amazonas (Ufam), Manaus, Amazonas, Brasil. E-mail: jrlreis@gmail.com

b. Doutor pelo Programa de Pós-Graduação em Biologia Tropical e Recursos Naturais, fruto do convênio entre o Instituto Nacional de Pesquisas da Amazônia (Inpa) e a Universidade Federal do Amazonas (Ufam). Docente do curso de graduação em engenharia florestal e do Programa de Pós-Graduação em Ciências Florestais e Ambientais (PPG-Cifa) da Universidade Federal do Amazonas (Ufam), Manaus, Amazonas, Brasil. E-mail: jucerote@hotmail.com

c. Mestre pelo Programa de Pós-Graduação em Biologia de Água Doce e Pesca Interior (PPG-BADPI) do Instituto Nacional de Pesquisas da Amazônia (Inpa), Manaus, Amazonas, Brasil. E-mail: lourdes.fischer.8@gmail.com 


\section{Resumen \\ Percepciones sobre el Turismo en Áreas Rurales: limitaciones y posibilidades en la APA Caverna do Maroaga, Presidente Figueiredo/AM}

El Turismo en las unidades de conservación es una alternativa para su sostenibilidad financiera y ambiental, con participación de la población local. A fin de entender este proceso en el área de protección ambiental (APA) de Caverna do Maroaga, se realizó una investigación exploratoria en tres comunidades de la APA Caverna do Maroaga, analizando la situación actual, las expectativas y las perspectivas de mejora de esta actividad, la percepción, el interés y la motivación de la comunidad. Se realizaron 87 entrevistas con adultos de las comunidades seleccionadas. Considerando que el turismo practicado en estas comunidades se dirige específicamente a los atractivos naturales, pero sin organización adecuada, se nota que la comunidad tiene interés y motivación para iniciar una directriz de gestión, sin embargo, les falta preparo para emprender o desarrollar programas, y además desconocen una posible oferta de cursos de capacitación necesarios para ello.

Palabras clave: Áreas rurales; Turismo; Unidad de conservación.

\section{INTRODUÇÃo}

A Amazônia é conhecida mundialmente pela exuberância de seus atributos naturais e pela cultura e diversidade étnica de seus habitantes, componentes diversificados para um mercado turístico cada vez mais segmentado, que conforma destinos turísticos. Nesse âmbito, o turismo desenvolvido em áreas rurais amazônicas pode melhorar a qualidade de vida das comunidades anfitriãs, principalmente em unidades de conservação (UC) de uso sustentável. A incorporação de métodos que conservem áreas naturais e/ou culturais - pré-requisitos básicos para sua sustentabilidade - têm oscilado com a ausência de apoio técnico, fomento e gerenciamento adequado em áreas de atividade turística massificada, gerando ônus ao ambiente físico e limitando o tempo de uso dos locais.

A atividade turística em territórios rurais é denominada "turismo rural", conceituada como "o conjunto de atividades turísticas desenvolvidas no meio rural, comprometido com a produção agropecuária, agregando valor a produtos e serviços, resgatando e promovendo o patrimônio cultural e natural da comunidade" (Brasil, 2001).

Na Amazônia observa-se que essa tipologia é voltada quase exclusivamente ao turismo de atributos naturais de propriedades rurais e adjacentes, em regiões afetadas ou não por UC públicas ou privadas, cuja recreação vem se apresentando como alternativa para o desenvolvimento econômico da região (Scherl et al., 2006). Assim a população local passa a preservar os recursos turísticos naturais e sua própria cultura (Lima, 2003).

A instituição e manejo de UC no Brasil seguem a Lei Federal no 9.985, de 18 de julho de 2000, que instituiu o Sistema Nacional de UC (Snuc), assim como seus decretos regulamentadores; e com a Lei Complementar no 53, de 5 de junho de 2007, em conformidade com o Snuc, o estado do Amazonas instituiu o Sistema Estadual de UC (Seuc).

A atividade turística pode ocorrer em UC, desde que devidamente licenciada e autorizada pelo órgão gestor e pelos conselhos gestores. No Amazonas, o Decreto Estadual no 30.873 , de 28 de dezembro de 2010, regulamentou o Seuc quanto às 
diretrizes para o uso público em UC. 0 estado é pioneiro na regulamentação da atividade turística em UC do Brasil.

Com exceção das categorias Reserva Biológica (Rebio) e Estação Ecológica (Esec), o turismo nas UC se dá mediante autorização do órgão gestor e a partir de acordos com comunidades, gerando renda, capacitação e empoderamento social. Para isso, a inclusão social das populações locais deve permear sua educação ambiental, visando não somente ações isoladas, mas uma transformação de conduta e, consequentemente, uma gestão legítima das áreas protegidas (Milano, 2000). Observa-se centenas de áreas no mundo todo que recebem o turismo de natureza, mas raros são os exemplos de comunidades bem-sucedidas tanto no desenvolvimento da comunidade quanto na proteção ambiental (Brandon, 1995). Sem dúvida, a participação dos moradores locais ainda é um desafio para o desenvolvimento local (Lima, 2003).

No Brasil, a Lei Federal no 11.771, de 17 de setembro de 2008, dispõe sobre a Política Nacional de Turismo e define as atribuições do Governo Federal no planejamento, desenvolvimento e estímulo ao setor turístico. Essa lei, dentre outros objetivos em seu artigo 5으, estabelece: a prática de turismo sustentável nas áreas naturais, promovendo a atividade como veículo de educação e interpretação ambiental; a adoção de condutas e práticas de mínimo impacto compatíveis com a conservação do meio ambiente natural; e parcerias interdisciplinares com entidades da administração pública federal, visando conservar e organizar o patrimônio natural e cultural para fins turísticos.

Contudo, Brandon (1995) adverte que, tanto em países desenvolvidos quanto subdesenvolvidos, as comunidades geralmente acreditam que não podem ser influentes nesse desenvolvimento. Dessa forma, projetos de turismo voltados à comunidade local envolvem as comunidades para que elas decidam o tipo de gestão que gostariam para, então, ajudá-las a implementá-la.

Na Amazônia o turismo tem sido incentivado em áreas afetadas de UC, cujo grupo de proteção integral passa por um processo gradual de inserção da população do entorno para se beneficiar de serviços indiretos (venda de artesanatos etc.) com o turismo praticado na região. Nas UC compostas por áreas públicas, busca-se elaborar um acordo de uso e benefício coletivo entre comunidades, turistas e operadores de turismo. Entretanto, as APA, por permitirem a coexistência de propriedades públicas e privadas, têm o desafio de repartir benefícios entre todos os envolvidos no turismo local.

Esse cenário pode ser observado na APA Caverna do Maroaga, UC estadual criada na década de 1990 no Amazonas. Saliente-se que essas políticas setoriais de desenvolvimento do turismo necessitam de diagnósticos precisos e rigorosos, que demonstrem o interesse dos comunitários, a oferta, a demanda e a viabilidade de implantar e manter os empreendimentos. As atividades turísticas planejadas ou em desenvolvimento nesse local devem seguir as diretrizes para uso público estabelecidas pelo Decreto Estadual nº 30.873/2010.

Dessa maneira, tendo em vista que a APA abrange áreas rurais, onde o turismo já ocorre mas apenas com o trabalho das 26 comunidades locais, além do fato de a região carecer de estudos que avaliem a situação atual de seu turismo, este artigo apresenta os resultados de uma análise ambiental sobre o desenvolvimento do turismo em três comunidades da APA, com foco em detectar os principais entraves dessa atividade e as possíveis oportunidades para seu desenvolvimento endógeno. 


\section{METODOLOGIA}

\section{Área de estudo}

A APA Caverna do Maroaga possui 374.700 ha, equivalentes a $14 \%$ do município de Presidente Figueiredo (AM). A UC está entre as coordenadas geográficas 1ำ1'35" e $2^{\circ} 16^{\prime} 02^{\prime \prime}$ de latitude sul e entre 59ํ1' $24^{\prime \prime}$ e $60^{\circ} 25^{\prime} 12^{\prime \prime}$ de longitude oeste de Greenwich. 0 local foi criado para "Proteger as belezas cênicas e atributos ambientais relevantes, e a proteção efetiva das cavidades espeleológicas do município de Presidente Figueiredo, em especial da Caverna Refúgio do Maroaga". A UC foi instituída pelo Decreto Estadual $n^{\circ}$ 12.836, de 9 de março de 1990, e retificado pelo Decreto no 16.354 , de 7 de dezembro de 1994, em relação a sua superfície. Tem como órgão gestor a Secretaria de Estado do Meio Ambiente do Amazonas (Sema-AM).

Figura 1 - APA Caverna do Maroaga e comunidades pesquisadas

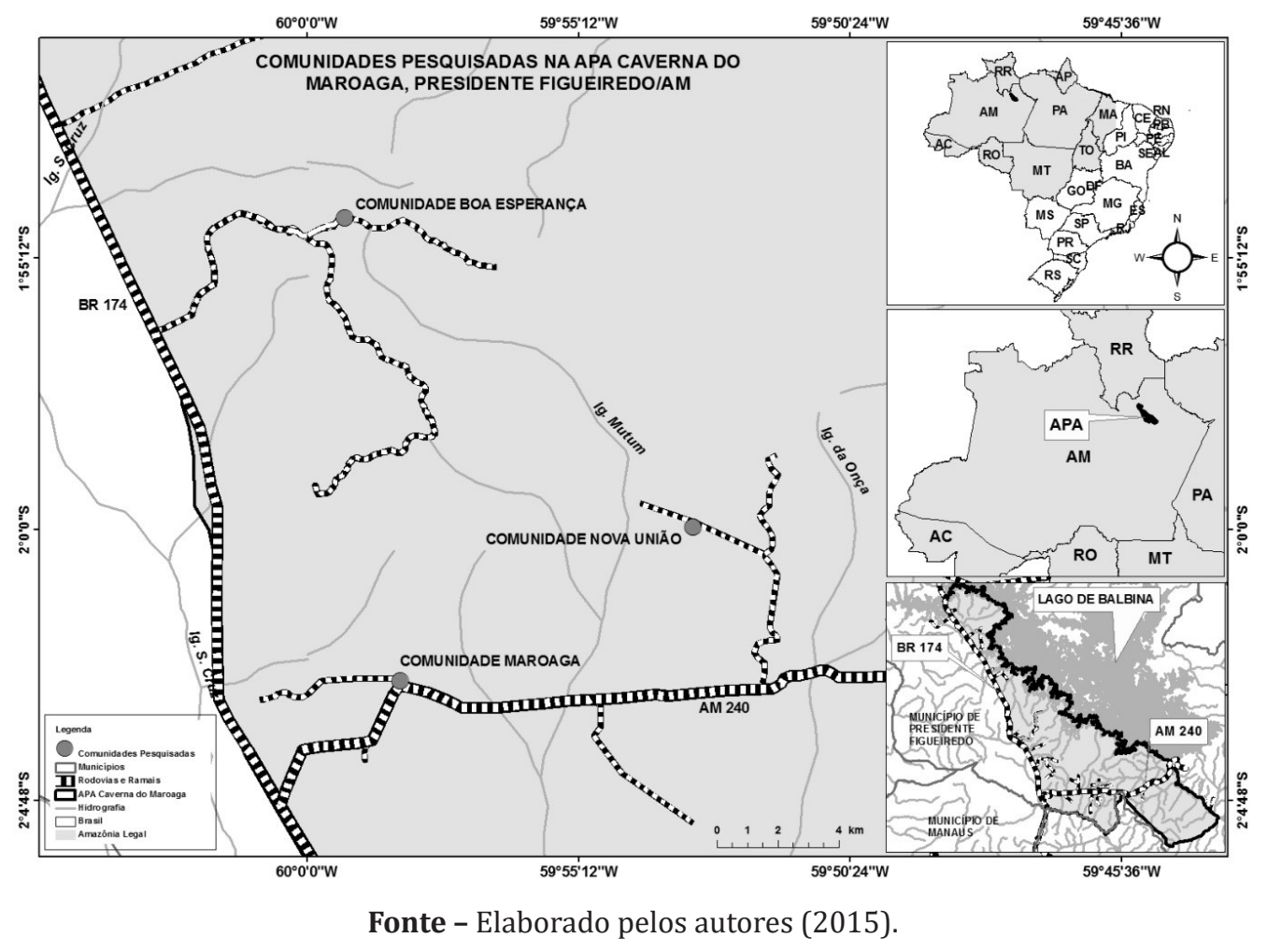

É a única APA do território amazonense com Conselho Deliberativo operante e plano de gestão aprovado. 0 Conselho Gestor foi criado pela Portaria Sema/GS no 114/2009. O Plano de Gestão foi aprovado pela Portaria Sema no 70/2012, com apoio da ONG norte-americana Gordon and Betty Moore Foundation. No interior da APA encontram-se 26 comunidades rurais, com cerca de 2.193 famílias (Amazonas, 2012). Dentre os fatores potencialmente responsáveis pelo crescimento econômico de Presidente Figueiredo nos últimos anos, destaca-se a pavimentação da rodovia BR-174, que possibilita a maior parte do escoamento terrestre estadual de produtos, jazidas minerais oriundas da região do Pitinga, da Usina Hidrelétrica de Balbina e suas infraestruturas. 


\section{Métodos e etapas da pesquisa}

Nossa investigação exploratória foi desenvolvida a partir de um estudo de caso, com análise bibliográfica e documental, e pesquisa de campo, com observação direta e coleta de dados e informações (Gressler, 2004; Marconi \& Lakatos, 2016; Yin, 2015). A pesquisa foi desenvolvida em três comunidades da APA Caverna do Maroaga (Figura 2). Essas comunidades foram escolhidas por desenvolverem atividade turística e devido a uma localização estratégica à margem de rodovias que cortam ou margeiam a APA. As entrevistas foram feitas com moradores das comunidades Boa Eperança, Maroaga e União.

Figura 2 - Fluxograma da estratégia metodológica

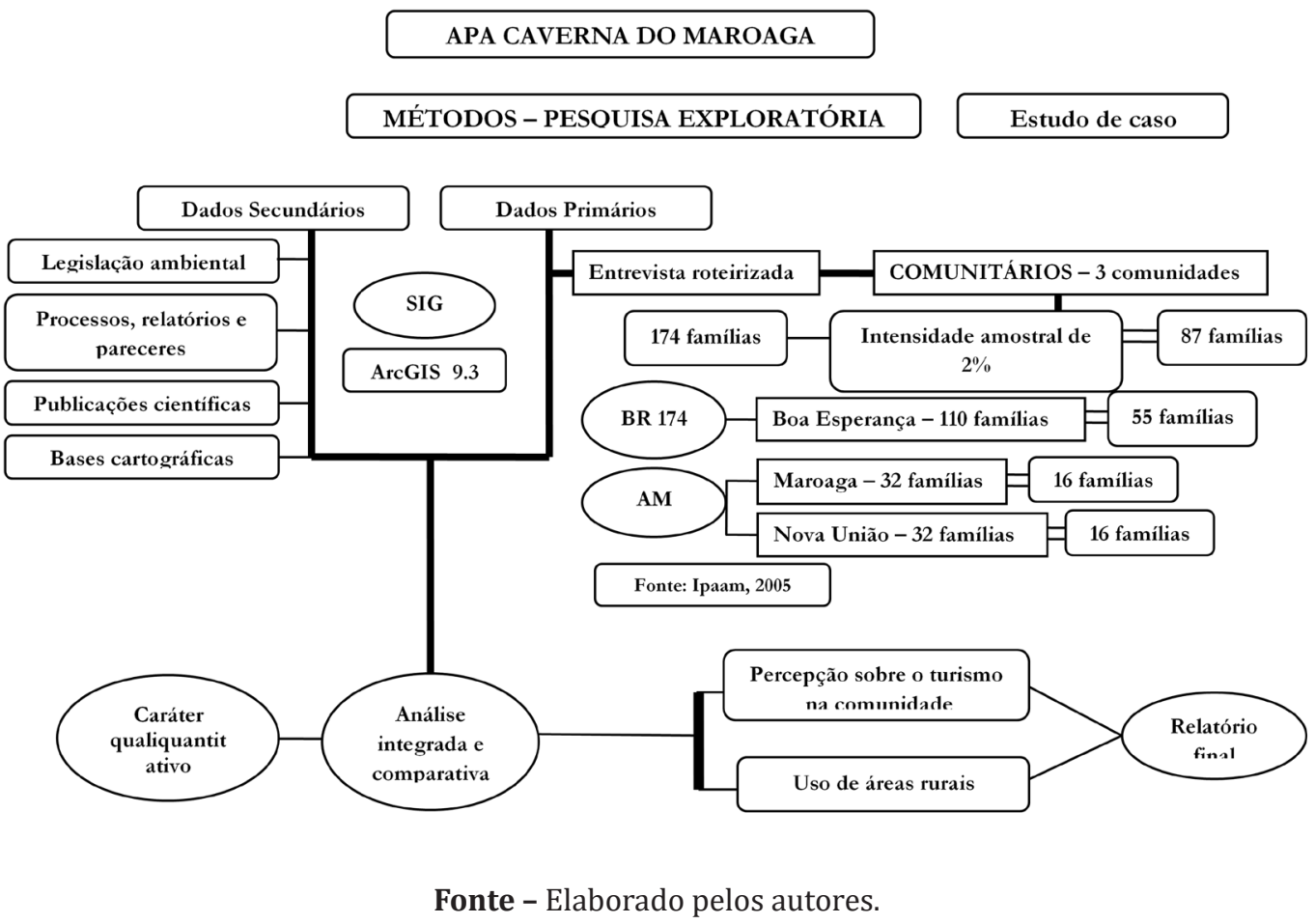

As unidades familiares foram selecionadas por amostragem, utilizando-se o número total de famílias por comunidade e aplicando-se a intensidade amostral de $2 \%$ de sua totalidade nas comunidades selecionadas. As amostras foram escolhidas aleatoriamente entre adultos dos dois gêneros, com o único critério de que morassem fixamente nas comunidades. Desse modo, sendo $50 \%$ a amostragem em cada comunidade, o número de famílias foi de 55 em toda a comunidade; e Boa Esperança e Maroaga, com 16 famílias cada, somaram 87 famílias amostradas.

Realizamos uma análise integrada dos dados e informações por meio de matrizes de interação e listagem de controle, relacionando a informação obtida por leventamentos primários e secundários com gráficos, tabelas ou diagramas, na estrutura de um modelo de interação (Fidalgo, 2003). Dessa forma, os dados dos formulários e os resultados das entrevistas foram analisados a partir de variáveis preestabelecidas. 


\section{RESULTADOS E DISCUSSÃo}

O surgimento de Presidente Figueiredo, marcado pela implantação de grandes empreendimentos, é a chave para compreender a atual situação de uso e ocupação da APA Caverna do Maroaga. Algumas marcas desse processo são visíveis, como o surgimento das comunidades ao longo da BR-174 e AM-240. 0 pioneirismo de ocupação da área substitui o avanço da exploração clandestina madeireira e de espécies específicas da fauna, como o galo-da-serra (Rupicola rupicola) (Omena Júnior \& Martins, 2007), e flora, como o pau-rosa (Aniba rosaeodora) (Mitja \& Lescure, 2000), endêmicas da região, que ainda persistem.

No decorrer desse processo, fazendas com pastagem para criação de gado ou sítios para agricultura intensiva sucumbiram perante a substituição da floresta, principalmente devido a pragas, solo infértil e ausência de logística e apoio técnico, o que causou o abandono, diante da inexistência de uma política agrária consistente (não assistencialista) para a região, de imensas áreas com pastagens, além do retorno intensivo à exploração clandestina de madeira (serrarias nas comunidades; ramais abandonados etc.) e exaustão de madeiras nobres (madeira, carvão e utensílios, com destaque para espetos). No entanto, nessa nova fase, a atividade turística ganha atenção, seja dos residentes das comunidades ou de outras regiões.

Para o turismo, valorizar as áreas rurais com atrativos naturais é uma oportunidade para complementar a renda familiar, e a pesquisa no interior da floresta é intensa e promove novas frentes de ocupação e exploração desenfreada. Os fins de conservação dessas áreas não são a principal meta, mas a garantia de uma nova ou única fonte de recursos financeiros.

De acordo com o Censo Agropecuário em 1995 e 1996, existiam na época 143 estabelecimentos rurais em Presidente Figueiredo, que correspondiam a 53.382 ha do município. Atualmente, o Censo de 2006 (IBGE, 2007) demonstrou que o número de estabelecimentos aumentou em mais de 22 vezes, chegando a 3.176 , ocupando uma área de 60.406 ha.

Os resultados demonstram o esforço dos ocupantes para regularizar suas áreas e atividades produtivas. No entanto, observa-se o aumento de apenas 7.024 ha em 10 anos (Censo Agropecuário de 1996 a 2006). Um dos possíveis motivos é a subdivisão da terra e sua venda em forma de lotes. Em 1996 as áreas cadastradas eram licenciadas, então a reserva legal dos empreendimentos foi eliminada por causa da comercialização da terra. Assim, o abandono de imensas áreas desmatadas - devido à inviabilidade de manutenção da atividade agrícola e a inexistência de ações para recuperar as áreas degradadas - motivou uma busca por novas estratégias de usar a floresta e seus atrativos naturais/culturais, impulsionadas pela capacitação do produtor rural e sua inclusão em novas frentes de trabalho, dentre elas o turismo.

Ao serem indagados, $52 \%$ dos entrevistados confirmaram a existência de turismo nas comunidades. Destes, $26 \%$ informaram que a visitação é voltada somente aos atrativos, de forma esporádica (Gráfico 1). Além disso, conforme relatado por $15 \%$ dos comunitários, não há organização nem estrutura apropriada nesses lugares; para $4 \%$, somente os guias credenciados pela Prefeitura Municipal de Presidente Figueiredo se beneficiam dessa prática; para 2\% não 
têm incentivo; e para 1\% está trazendo lixo. Desse modo, pode-se afirmar que ocorre turismo de massa, mas poucos residentes são beneficiados direta ou indiretamente.

Gráfico 1 - Turismo nas comunidades da APA Caverna do Maroaga

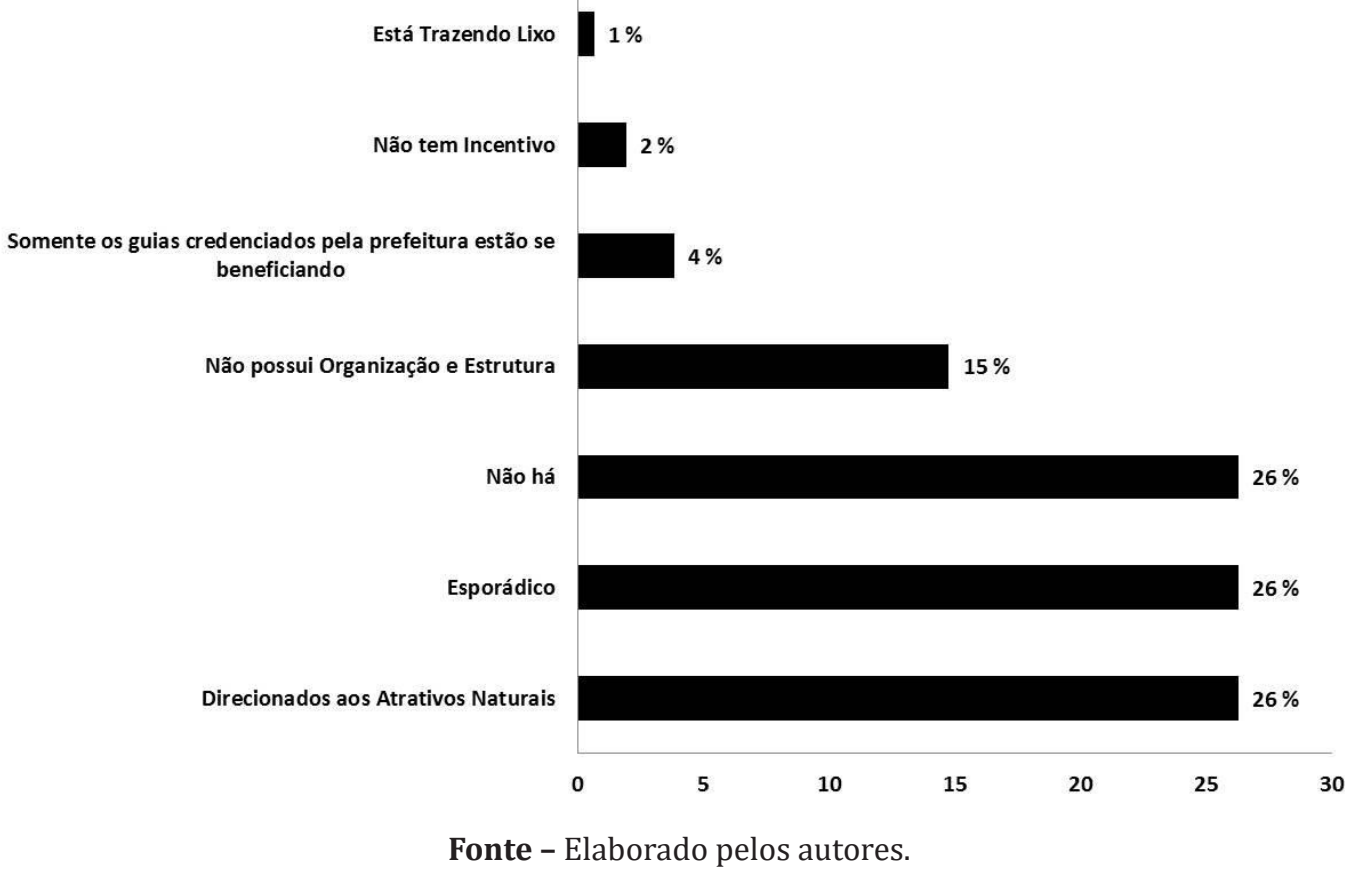

Observa-se que o turismo nas comunidades está sendo feito de forma incipiente e sem controle sobre o uso de recursos naturais, além da ausência de incentivo técnico e financeiro para estruturar a comunidade e os atrativos. Destaca-se também a seleção de profissionais treinados para a atividade, que concentram o serviço de guia turístico e utilizam de forma desrespeitosa os atrativos das propriedades dos comunitários, sem sequer solicitar autorização a eles.

Para 80,9\% dos entrevistados, o turismo praticado na comunidade não traz benefícios coletivos, contra apenas 19,1\% que pensam o contrário (Gráfico 2), com os seguintes fatores: contratação de comunitários para gerenciar e guiar atrativos $(6,4 \%)$; fortalecimento do comércio $(6,4 \%)$; troca de experiências $(4,3 \%)$ e oferta de cursos de qualificação $(2 \%)$.

Cabe observar que essas ações são expectativas de grande parte dos comunitários. No entanto, existem ações pontuais de qualificação profissional para o turismo, vinculadas geralmente a órgãos da esfera administrativa local e/ou moradores da área urbana. Poucos ou inexistentes são os residentes desvinculados de órgãos de governo com acesso a esses programas.

Sobre a perspectiva do turismo (Gráfico 3), 83,1 \% dos entrevistados não observam ações efetivas para implantá-lo na comunidade. Para $12,4 \%$ a atividade turística pode trazer capacitação técnica e incentivo financeiro pelo poder público. Além disso, 3,4\% têm esperança de regularizar sua posse de terra, e 1,1\% acredita que somente os grandes proprietários, donos de cachoeira, serão beneficiados. 
Gráfico 2 - Benefícios do turismo nas comunidades

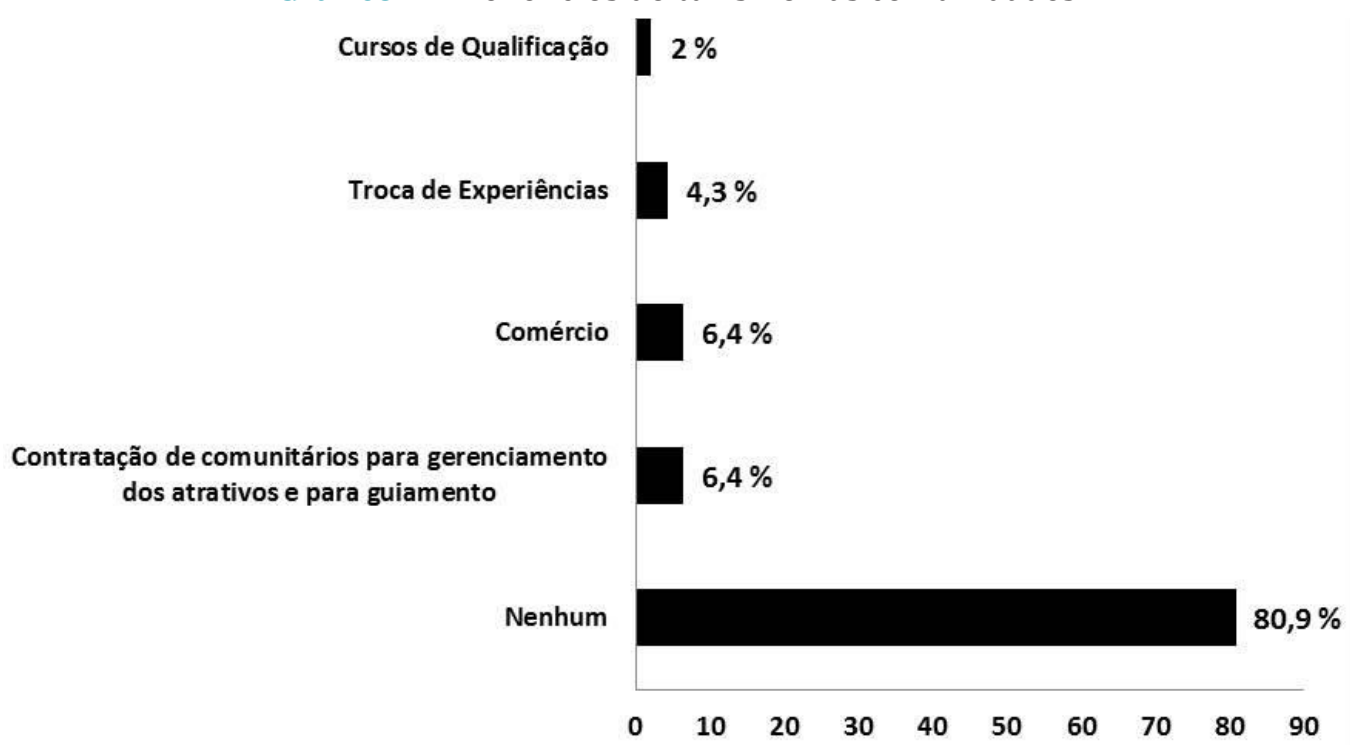

Fonte - Elaborado pelos autores.

Gráfico 3 - Perspectiva do turismo na comunidade

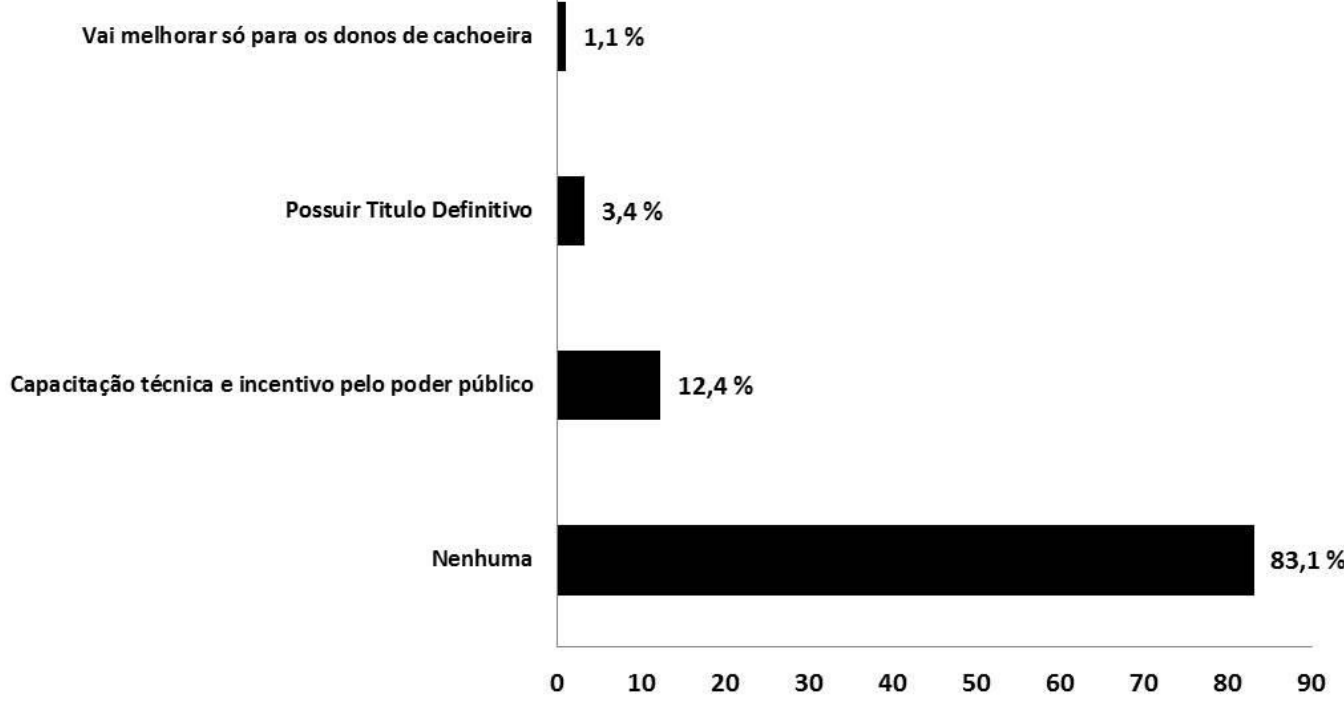

Fonte - Elaborado pelos autores.

Os grandes empreendimentos turístico-hoteleiros implantados na Caverna do Maroaga foram responsáveis por uma mudança de atitude com os residentes das comunidades, que almejavam um ingresso no mercado turístico. No entanto, a ausência de orientação técnica na busca de apoio financeiro e no gerenciamento dos atrativos naturais da área são as principais ameaças à continuidade de seu uso. Além disso, essa expectativa é positiva para reivindicar ações pontuais de regularização fundiária e reconhecimento dessa atividade e suas necessidades.

Quando indagados sobre os aspectos negativos do turismo na comunidade (Gráfico 4), 75\% relataram que a atividade não gera nenhum impacto. No entanto, $6 \%$ relataram depredação de atrativos, devido principalmente à não seletividade de visitantes (5\%), ausência de qualificação e de manutenção (4\%), 
poluição de atrativos (3\%), aumento dos dejetos sólidos (2\%), além da modificação no padrão de vida e no cotidiano da comunidade (2\%). Este último aspecto é primordial, principalmente por causa do aumento no fluxo migratório da área urbana para rural e da transformação de comunidades em vilas, ou seja, o surgimento de microáreas urbanas.

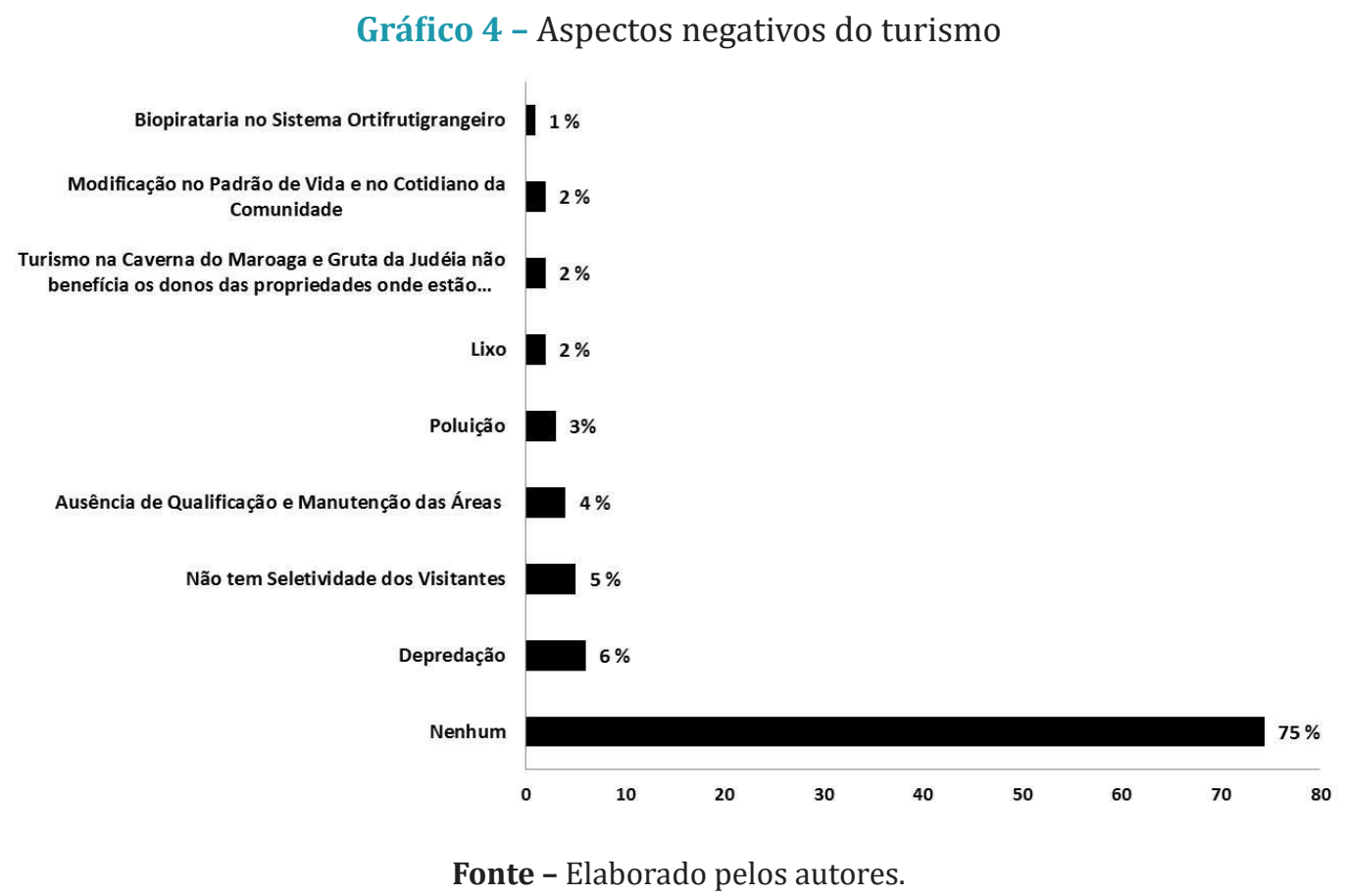

Para 2\% dos comunitários o turismo praticado na Caverna do Maroaga e na Gruta da Judeia não beneficia os donos das propriedades locais, mas somente os guias da Prefeitura de Presidente Figueiredo. Essa questão é de extrema importância para os comunitários, principalmente os proprietários de atrativos turísticos.

A intervenção não autorizada dos órgãos de governo nos atrativos naturais chama atenção, haja vista não ser assinado nenhum documento com os proprietários que respalde a ação dos guias - credenciados pelo poder municipal - para acessar as áreas, e o turismo não dá retorno financeiro aos proprietários em condições precárias, que sofrem restrições de uso. Além disso, 1\% dos entrevistados citaram a biopirataria no sistema hortifrutigranjeiro como um dos principais aspectos negativos do turismo na região.

Por outro lado, observa-se a percepção dos comunitários sobre a importância da manutenção das áreas naturais e do avanço da degradação sobre elas, o que sugere uma busca por ações mais concretas para estruturar e regulamentar o turismo na área rural. Essa mudança, que visa substituir a exploração desenfreada pela valorização de atividades ecoturísticas nas áreas naturais, exige dos gestores da UC e outras esferas do governo um planejamento do uso público dessas áreas.

Apesar de o turismo nas comunidades da Caverna do Maroaga oferecer diversas atividades que envolveriam direta ou indiretamente a população local, $76 \%$ dos entrevistados alegam não desenvolvê-las com os visitantes, contra $24 \%$ que afirmam o contrário; e 70\% não trabalham com nenhum tipo de atividade turística. 
Os serviços elencados pelos entrevistados são: (1) atuação como guia local ou da comunidade (14\%); (2) venda de artesanato e doces/produtos in natura e beneficiados (6\%); (3) venda de bebidas (3\%); (4) oferta de hospedagem (2\%); (5) estímulo ao comércio (2\%) (Gráfico 5).

Gráfico 5 - Serviços desenvolvidos com os visitantes: a) Trabalha com visitantes da comunidade?; b) Quais serviços desenvolve com eles?

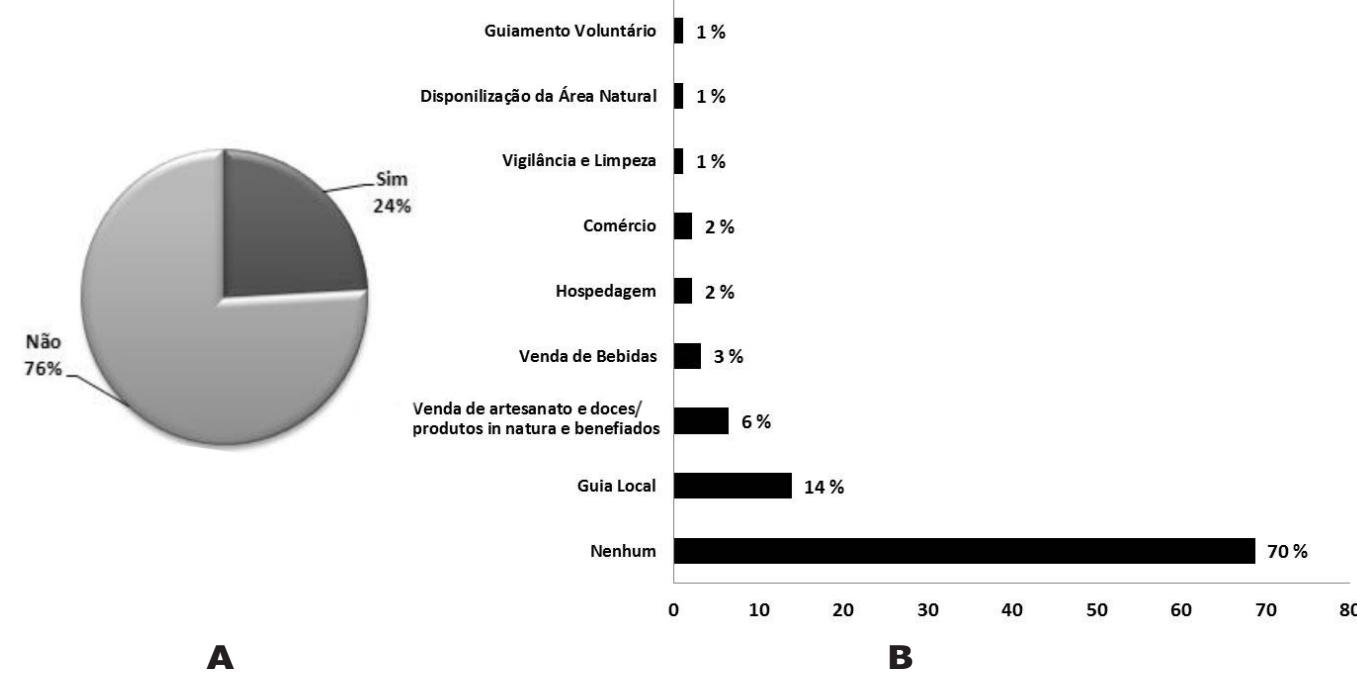

Fonte - Elaborado pelos autores.

Sobre a gestão direta dos atrativos naturais, apenas 1\% dos entrevistados relataram trabalhar com sua vigilância, limpeza e disponibilização para visita, cobrando pela entrada de turistas ou como guia voluntário. Observou-se que a atividade turística tem impacto direto na economia local e nos locais de destino, criando novas alternativas de trabalho aos comunitários e impulsionando a vida comercial das comunidades, o que demonstra a vitalidade e variedade de opções dos comunitários para agregar valor ao produto turístico que sua comunidade oferece. No entanto, eles ainda sofrem com a ausência de infraestrutura, qualificação profissional e fomento.

A motivação quanto à implantação do turismo nas propriedades rurais também foi indagada, e a maioria dos entrevistados confirmou interesse (45\%) em visitas turísticas nas áreas sob sua posse; $43 \%$ não têm esse interesse, por diversas causas. Além disso, 8\% relataram que as visitas já acontecem, e 4\%, que ocorrem sem consentimento do proprietário. Isso é importante para ampliar a discussão sobre a violação do direito de propriedade e da ausência de regras claras aos guias credenciados pela Prefeitura de Presidente Figueiredo sobre como organizar visitas a atrativos naturais em propriedades privadas no interior da APA Caverna do Maroaga.

Sobre a motivação para a atividade turística, os entrevistados informaram que seu grande interesse é o ganho financeiro (43\%), tanto como complemento da renda familiar como, em alguns casos, a única fonte de recursos. No entanto, $40 \%$ acreditam que não há expectativas para uma solução desses problemas, haja vista as dificuldades para manter o negócio e aperfeiçoá-lo (Gráfico 6). 
Gráfico 6 - Interesse no turismo em comunidades da APA Caverna do Maroaga:

a) Interesse na visitação turística; b) Motivação no turismo

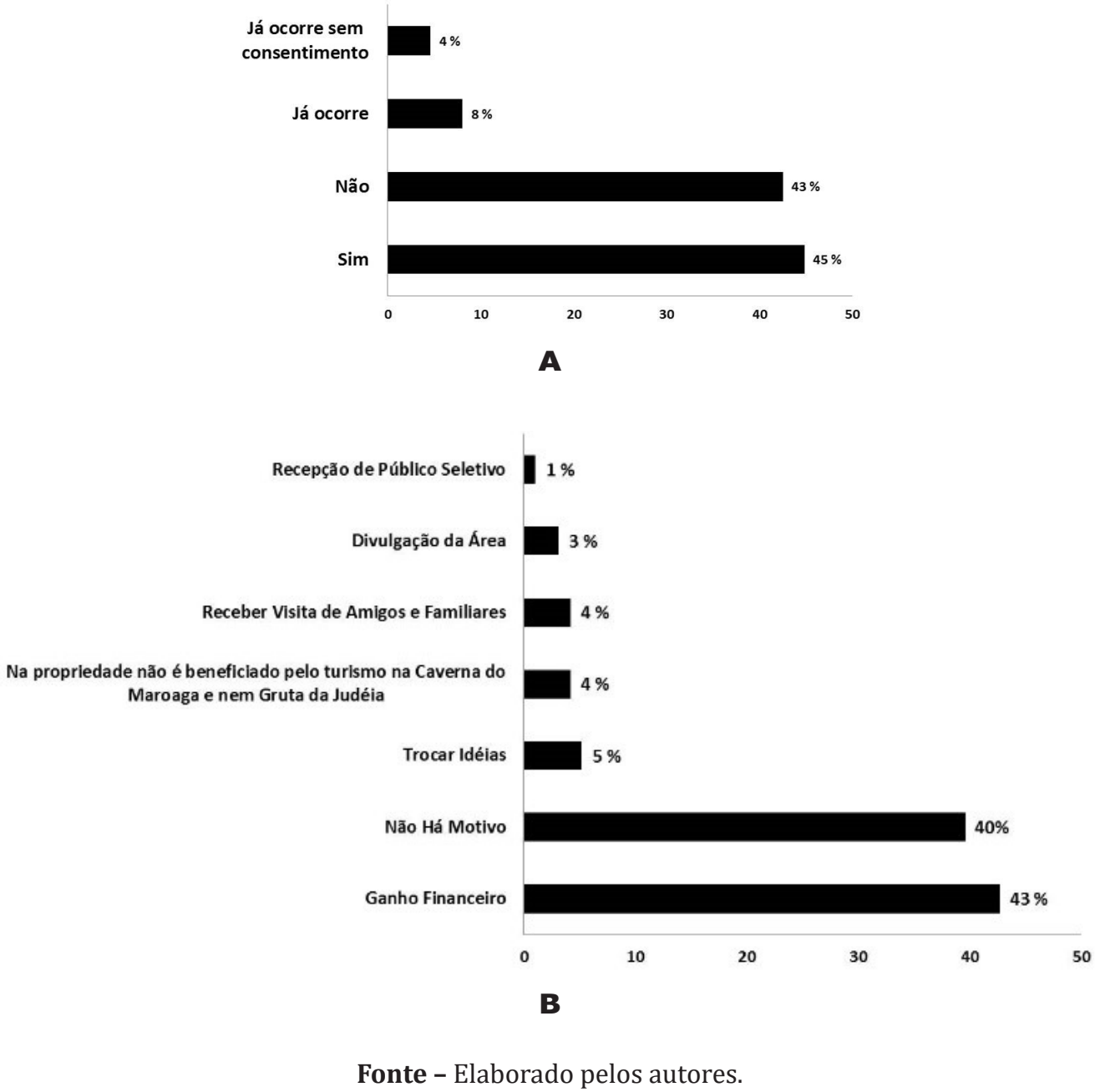

Os dados mostram que 5\% dos entrevistados destacaram a troca de ideias como principal motivação para as visitas, além da recepção de amigos e familiares (4\%) e divulgação da área (3\%). Os comunitários valorizam a presença de público qualificado (pesquisadores, técnicos de órgãos etc.) como primordiais para conservar essas áreas. Destaca-se que 4\% dos entrevistados que residem no entorno da Caverna do Maroaga e da Gruta da Judeia não se beneficiam com o turismo em suas propriedades, problema que deve ser solucionado imediatamente.

Os atributos naturais dessa região são de extrema importância para organizar a visitação turística. Dessa forma, 25,2\% dos entrevistados informam que suas propriedades contêm floresta, $17,6 \%$ de igarapés e $14,7 \%$ de nascentes. No entanto, $7,6 \%$ relataram a existência de plantações com cultura diversificada. Os atrativos espeleológicos foram citados, como rochas expostas (6\%), cachoeiras $(3,5 \%)$, cavernas e grutas $(2,9 \%)$, corredeira $(1,8 \%)$ e gruta $(1,8 \%)$. As áreas com pastagem receberam 1,2\% de citação, e as áreas com reprodução de fauna tiveram destaque $(4,7 \%)$ (Gráfico 7$)$. 


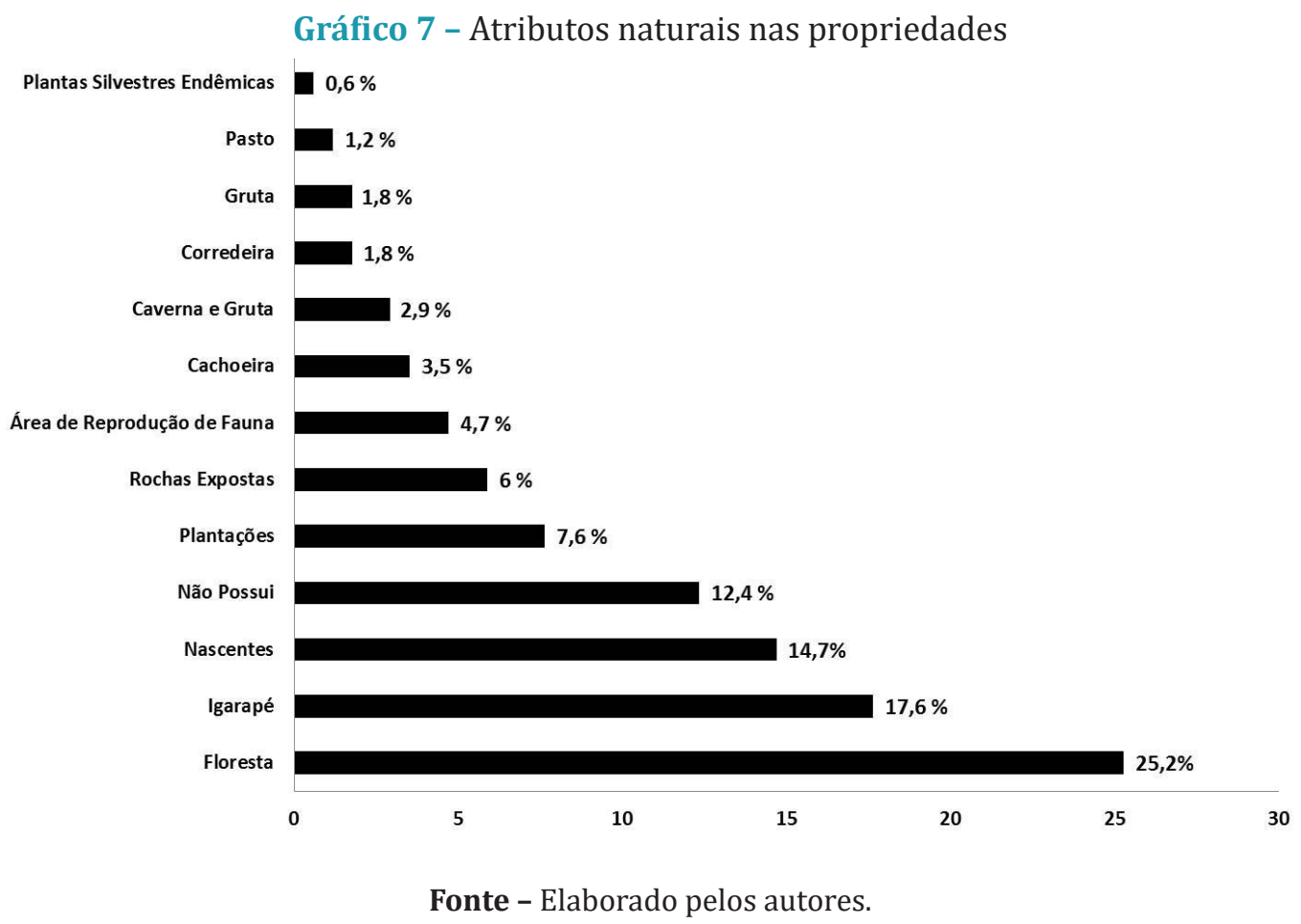

Somente 3,5\% dos entrevistados alegam ter "cachoeiras" em suas propriedades, um dos mais reconhecidos atributos naturais. Sua inexistência demanda a valorização de outras áreas até então pouco utilizadas para visitação, possibilitando novas atividades recreativas de lazer e um público mais seletivo e segmentado.

A situação de uso das áreas rurais é abordada de forma bastante significativa. A maioria das propriedades não é visitada (48\%). Das visitadas, 16\% recebem visitas guiadas; $15 \%$, entrada livre, com valor fixo para manutenção da área; $10 \%$ recebem visitas esporádicas e grupos dirigidos; em $9 \%$ há apenas recepção e café aos visitantes; e em $2 \%$ os proprietários não têm nenhuma noção de como o processo ocorreria. Muitos comunitários têm dimensão da importância de garantir comodidade aos visitantes, o que implica também uma disposição de informações relevantes sobre os locais de visitação e o mínimo de conforto, sem perder a originalidade do mundo rural (Gráfico 8).

De acordo com os entrevistados, um dos principais fatores que impedem a evolução do turismo na região é a ausência de financiamento (16\%) ou o desconhecimento de linhas de auxílio e procedimentos necessários para incentivá-lo. Some-se a isso desqualificação (13\%) e infraestrutura inadequada para estadia e alimentação dos visitantes (12\%). A desorganização da comunidade e a ausência de visão crítica quanto aos problemas enfrentados pela comunidade é um fator relevante (16\%), principalmente na mobilização social para reivindicar melhorias.

A influência política nas áreas naturais (6\%) é, na visão dos entrevistados, o maior problema atual das comunidades, pois os políticos locais se apropriam de áreas que poderiam ser destinadas à criação de UC municipais. Outro problema é a ausência de titulação das terras pelo Instituto Nacional de Colonização e Reforma Agrária (Incra) e Instituto de Terras do Amazonas (Iteam). As grandes propriedades com título definitivo e capital para investir na estrutura das áreas para o turismo (3\%) inibem as de menor porte, em razão de escassas políticas de apoio técnico e fomento, haja vista a pequena oferta de áreas naturais (3\%) com atrativos 
naturais de interesse e propícios a visitação, além da pobreza rural (8\%) e ausência de recursos próprios para investir na região, resultado do medo dos pequenos proprietários de se endividar com os órgãos de fomento/financiamento.

Ressalta-se também a precariedade dos serviços públicos na manutenção de ramais (1\%) e estruturas básicas de acesso às comunidades, como escolas, poço artesiano, sedes etc. Um fator prioritário, citado por apenas 1\% dos informantes, são parcerias com a iniciativa privada, sendo inexistente qualquer vínculo das agências turísticas com comunidades. Somente a Cachoeira Santuário tem uma parceria consolidada, haja vista seu investimento para hospedagem, alimentação e realização de eventos.

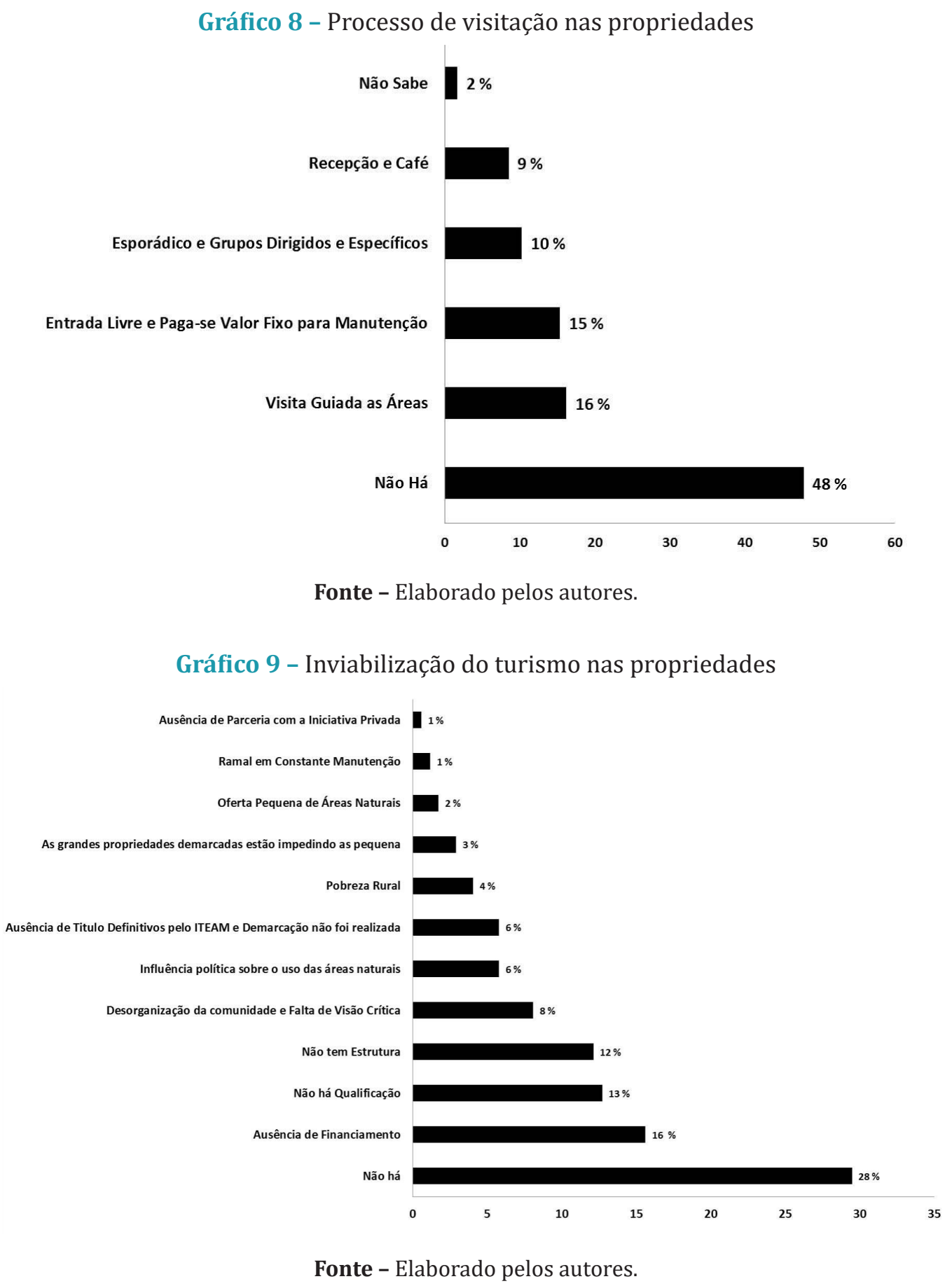


O Censo Agropecuário 2006 (IBGE, 2007) apresenta a ocupação da terra em Presidente Figueiredo, expondo 986 estabelecimentos, que totalizam uma área de 60.371 ha. Destes, pode-se verificar que 39, somando uma área de 1.547 ha, são frequentados por "ocupantes". Observa-se também que em 2017 esse número já é bem maior, devido à grande expansão das comunidades, bem como a atual fase de implantação do programa Terra Legal, que prevê a regularização fundiária das terras em áreas da União, no âmbito da Amazônia Legal, com planejamento para a região de Presidente Figueiredo. Um ponto importante é a implementação do Cadastro Ambiental Rural (CAR), instituído pela Lei Federal no 12.651, de 25 de maio de 2012 - o novo Código Florestal.

Cabe salientar atividades voltadas ao pagamento por serviços ambientais em fase embrionária de regulamentação na Amazônia. Segundo Ferreira e Silva (2008), nas regiões de florestas naturais com alta disponibilidade de madeira acessível a baixo custo, essa fonte ainda será uma opção. Entretanto, esse recurso deverá ser explorado em regimes de baixo impacto, que assegurem a manutenção da biodiversidade, elevando o custo da madeira. Analisando as tendências atuais, a motivação primordial para manter as florestas naturais remanescentes em outras regiões, com exceção da Região Amazônica, será o lazer e a obtenção de serviços ambientais.

Quando indagados sobre a situação socioambiental da comunidade (Gráfico 10), a maioria dos comunitários $(39,8 \%)$ relataram o aumento da população/moradores, o que se relaciona com o aumento do desflorestamento $(8,7 \%)$, ocupações espontâneas (8\%), venda clandestina de lotes $(7,5 \%)$ e redivisão de lotes $(6,8 \%)$, originando conflitos de terra (3,1\%). Possíveis fatores são a migração da área urbana para a área rural $(2,5 \%)$, devida, principalmente, à oferta de trabalho nos plantios de pimenta, ao aumento das áreas de cultivo $(5,6 \%)$ e à melhoria das condições de acesso a comunidades e estrutura básica (5\%), como escolas, eletrificação rural $(1,9 \%)$, coleta de lixo $(1,2 \%)$, entre outros. Outro aspecto que merece ser citado é a oferta de terras para ocupação, repassada pelos órgãos fundiários ou indicada pelos líderes das comunidades, em alguns casos.

Um dos aspectos negativos é a venda de carvão (2,5\%), que demonstra uma grande demanda por madeira na comunidade, obtida de forma ilegal. As comunidades apresentam desorganização política e administrativa, e os comunitários estão desunidos (1,9\%). Destaque-se a ausência dos recursos do Programa Nacional de Fortalecimento da Agricultura Familiar (Pronaf) com 1,2\% das citações, principalmente aos moradores do projeto de assentamento (PA) Uatumã e as comunidades selecionadas para implementação do programa Turismo Rural da Agricultura Familiar (Traf). Apenas 0,6\% dos entrevistados citaram o aumento de animais abandonados.

Esses aspectos mostram a extrema pobreza e negligência por parte do poder público para atender as demandas das comunidades, à mercê das articulações políticas ou do envolvimento político-partidário para conseguir representatividade. Digno de nota são as comunidades "beneficiadas" pelo prefeito, em detrimento de outras que ficam à margem dos serviços por discordarem das ações fragmentadas e político-eleitoreiras.

O desflorestamento (Figura 3) ocorre primeiramente com a abertura de ramais, com desmatamentos muitas vezes não autorizados pelo poder público. Em seguida, são abertos caminhos ou "picadas" na floresta, que conduzem a clareiras, cujas árvores são derrubadas com maior potencial e organizadas em forma 
de "prancha". Os infratores tomam cuidado para não desmatar por completo a área, retirando apenas as de maior porte, camuflando o desmatamento. Depois, as pranchas de madeira são escondidas na entrada do ramal ou no seu entorno. Geralmente são levadas à serraria ao final da tarde, localizada na comunidade ou na sede do município.

Gráfico 10 - 0 que mais aumentou na comunidade nos últimos anos.

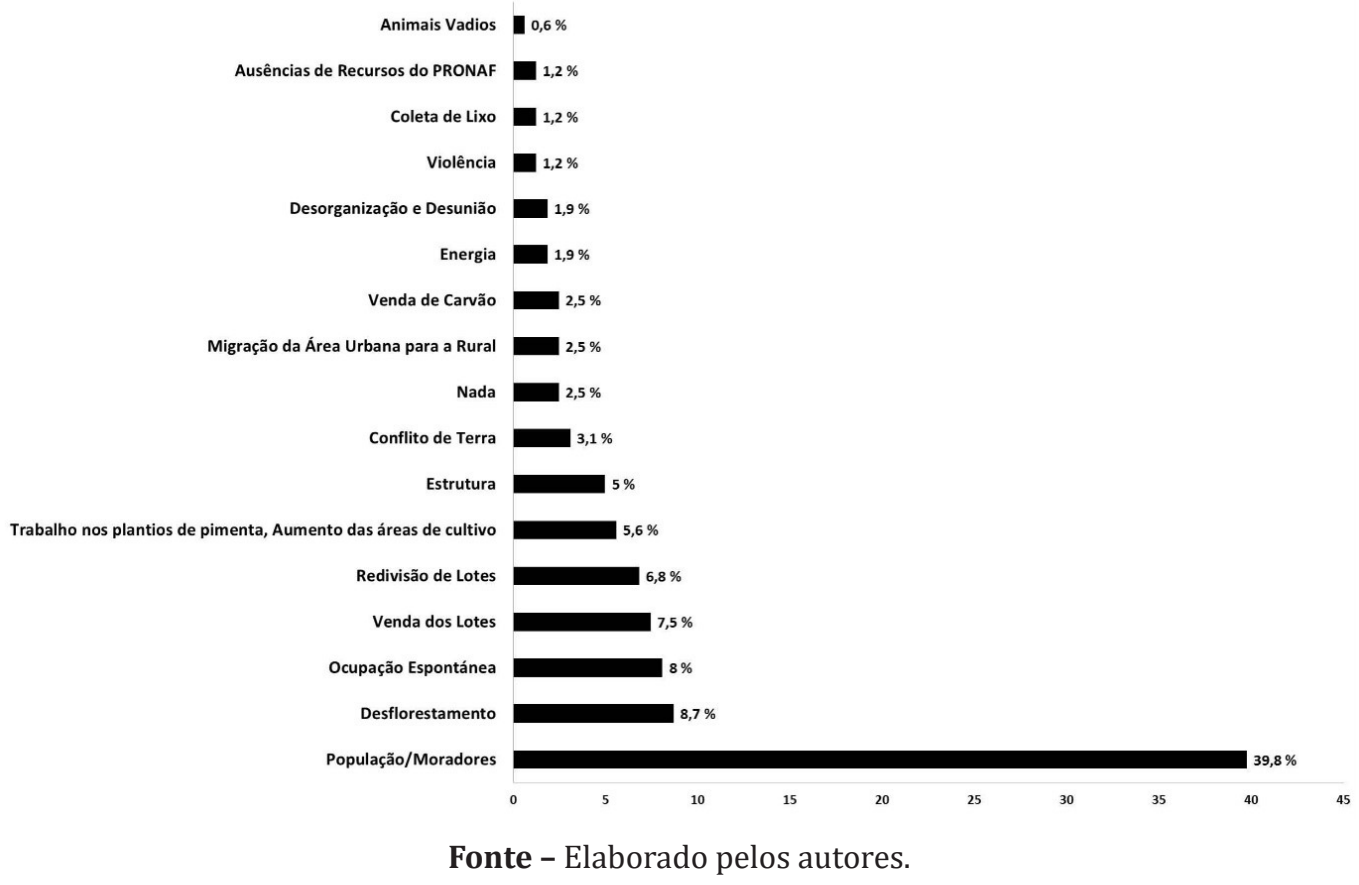

Figura 3 - Ciclo do desflorestamento: a) Árvore cortada na floresta; b) Pranchas de madeira; c) Sobras de madeira na floresta; d) Abertura de ramais; e) Retirada ilegal de madeira - pranchas de madeira escondidas entre arbustos na entrada do ramal; f) Serraria na comunidade
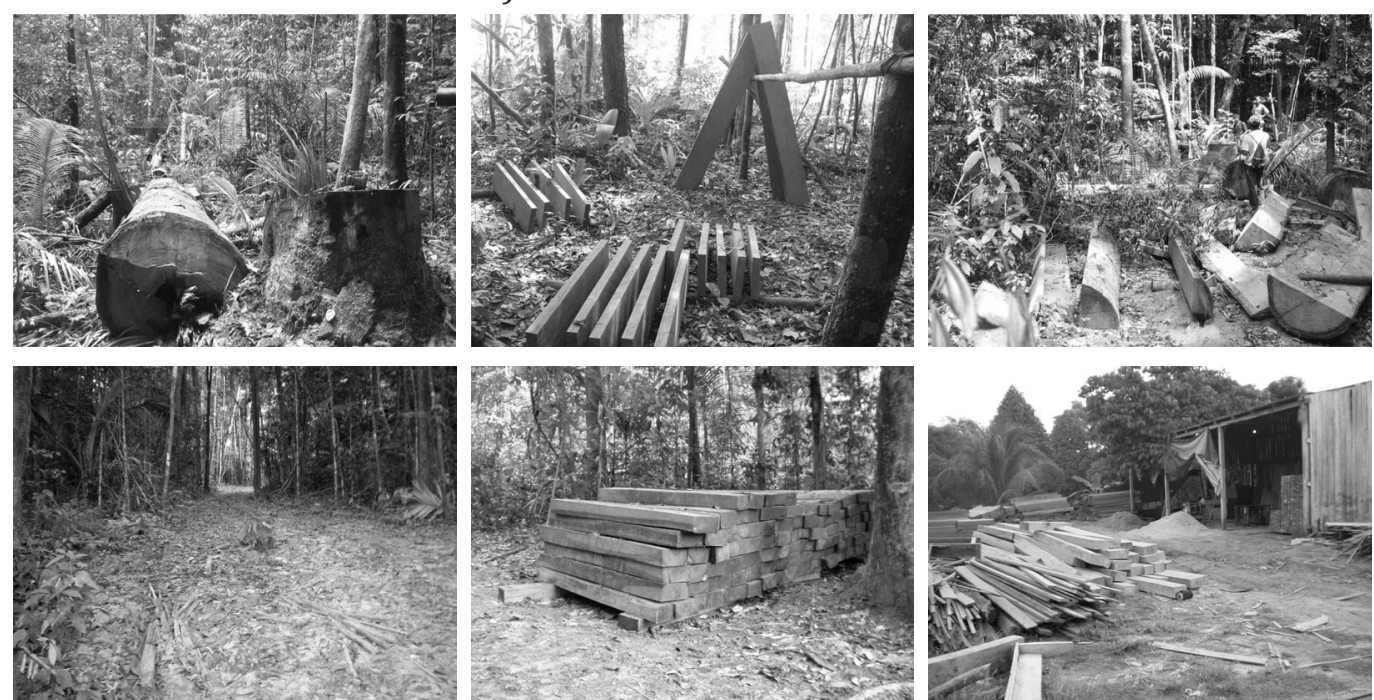

Fonte - Elaborado pelos autores (2013).

Para solucionar os problemas, os entrevistados sugeriram capacitação técnica e incentivo pelo poder público $(24,6 \%)$, uma das principais estratégias para 
resolver os entraves administrativos e de gestão nas comunidades. Esses aspectos são a base para conduzir uma política concreta e regulamentar o ecoturismo na APA Caverna do Maroaga atualmente. Para isso, é necessário um bom desempenho por parte dos comunitários, que devem reivindicar soluções concretas e não simplesmente paliativas, como também exigir uma atuação "real” dos órgãos ambientais no controle ambiental e gestão das áreas protegidas (Gráfico 11).

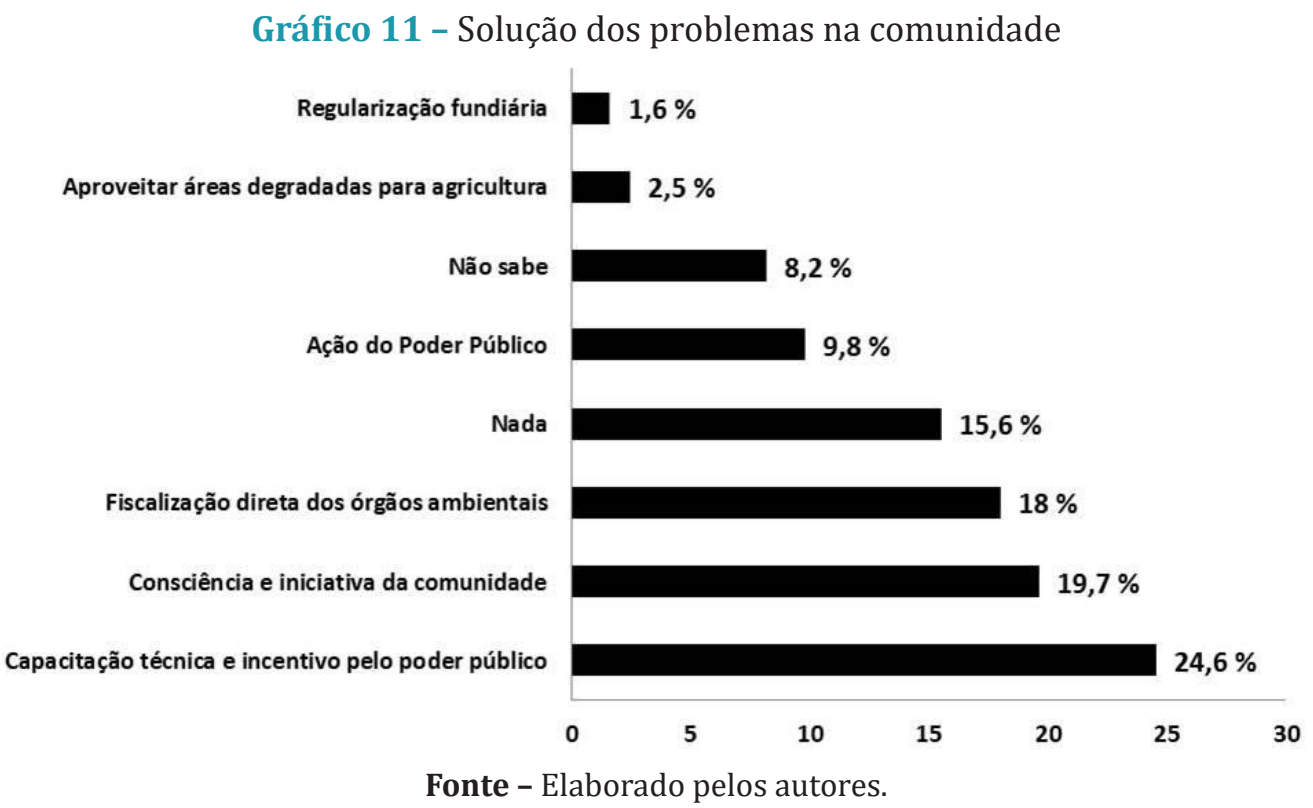

Portanto, as ações governamentais $(9,8 \%)$ são prioritárias e, dentre estas, está a fiscalização direta dos órgãos ambientais às infrações, ao licenciamento e monitoramento dos empreendimentos $(18 \%)$ e regularização fundiária $(1,6 \%)$, essenciais para buscar investimento. Além disso, deve haver consciência e iniciativa da própria comunidade $(19,7 \%)$ na reivindicação de soluções.

Os comunitários sabem da importância das ações de combate e controle do desflorestamento e quão prejudicial ele pode ser para a manutenção ecológica. Dessa forma, citam como primordial o aproveitamento de áreas degradadas para agricultura (2,5\%), impedindo o avanço das áreas de cultivo sobre a floresta. Além destes fatores, 15,6\% acreditam que nada deveria ser feito, e 8,2\% não souberam responder a pergunta.

Cabe ressaltar a importância da mudança de visão dos comunitários sobre o uso da floresta e dos atributos da região. A antiga visão de exploração maciça está sendo substituída pela reivindicação de ações concretas para solucionar a degradação ambiental que ameaça os atrativos e, consequentemente, seu uso turístico. A tomada de consciência precede o valor pela área natural, como fonte de recursos e de lazer.

Um ponto-chave para proteger essas áreas é a instituição de UC públicas e privadas, buscando-se um ambiente favorável, principalmente com empreendimentos-reservas, visualizados pelos comunitários como modelos a serem seguidos. Contudo, ainda é necessário criar ações claras de apoio à implementação das UC por parte do Estado.

Por outro lado, o turismo em áreas rurais necessita de condições favoráveis. Uma organização político-comunitária é essencial, além de investimentos 
públicos em infraestrutura básica nas comunidades, principalmente na manutenção dos ramais e ampliação da rede elétrica rural. E o fomento ao turismo deve ser guiado por ações de caráter participativo e deliberativo, principalmente para implantar infraestrutura turística (como placas de identificação nos atrativos) e roteirização dos locais para visitação.

Observa-se por outro ângulo que os programas nacionais de fomento ao turismo sempre trazem os mesmos interesses, voltados justamente a criar condições favoráveis e satisfatórias ao desenvolvimento turístico. Pelo contrário, essas ações sempre esbarram na ausência de condições mínimas de apoio e até pelo desinteresse ou ausência de capacitação dos agentes locais para atuar de forma mais ativa e consistente. Dessa forma, mais uma expectativa é alimentada pelo pequeno agricultor que, sem capital de giro, depende de promessas ou programas que tentam resolver o grande impasse ambiental-fundiário-turístico deixado como herança para essa, ou melhor, para as gerações futuras.

Na APA observa-se a ausência de ações de capacitação comunitária e fomento ao turismo, apesar de a UC ser objeto de atuação de importantes programas do Governo Federal:

a) O Programa de Desenvolvimento do Ecoturismo na Amazônia Legal (Proecotur), que apoiou um importante produto de planejamento para essa UC: o plano de manejo espeleológico para dois atrativos da APA (Caverna do Maroaga e Gruta do Batismo);

b)O Traf, do Ministério do Desenvolvimento Agrário (MDA), está em fase inicial e tem como objetivo: promover o desenvolvimento rural sustentável através da implantação e fortalecimento das atividades turísticas pelos agricultores familiares, integrado aos arranjos produtivos locais na adequação e implantação de infraestrutura, no estudo de legislação e de regulamentos técnicos, na criação de um ambiente favorável para ser inserido no mercado nacional, melhorando as condições de vida local. Apenas a comunidade da Boa Esperança inserida na APA participa desse programa.

Para o ecoturismo, o cotidiano das comunidades também é um atrativo, cujo centro é o contexto histórico de ocupação e uso de recursos naturais, incentivando a continuidade de conhecimentos e práticas para um usufruto e uma produção saudável. É necessário regulamentar o uso de determinadas áreas para conservar sua biodiversidade e produção.

\section{CONCLUSÕES}

Na Amazônia observa-se que o turismo rural é desenvolvido em poucas comunidades por diferentes motivos, além de ser pouco estudado. 0 desenvolvimento da atividade turística nas UC estaduais ainda está em fase de estruturação, sendo pouco estimulado pelo Poder Público. Observa-se também que os locais turísticos são informais e impulsionados pela visitação de atrativos naturais, sejam cachoeiras, cavernas, áreas de igapó, inscrições rupestres, espécies animais endêmicas ou de interesse da pesca esportiva.

Retratando o desenvolvimento do turismo em áreas rurais na Amazônia, a APA Caverna do Maroaga é um exemplo de que essa atividade econômica, direcionada aos atrativos turísticos naturais, não é bem organizada e não gera renda para as 
comunidades. Dessa forma, a operação turística carece de monitoramento ambiental, envolvimento social, distribuição de renda e planejamento, o que transforma essa atividade em turismo de massa, descaracteriza a paisagem e compromete o futuro os atributos naturais da UC, impactando a rotina e os costumes comunitários.

Os comunitários têm interesse e motivação para o turismo, porém não estão preparados para estabelecer empreendimentos nem recebem orientações sobre as possíveis cursos de capacitação em administração de visitantes e empreendedorismo. Uma APA prescinde expropriação e atuação das comunidades, sendo um fator significativo para equacionar situações sem soluções práticas ou expor a negligência dos órgãos públicos. Por isso, é vital constituir uma mentalidade empreendedora que reivindique ações mais consistentes pelo poder público, ou propiciar, por meio do associativismo, investimentos nas áreas e na contratação de consultorias, para elaborar estudos condizentes, que visem o uso apropriado da região e garanta novas oportunidades de trabalho aos comunitários.

Dessa forma, destaca-se a necessidade de:

1)Elaborar estudos sobre oferta/demanda turística: a administração do turismo na UC deve atender necessidades básicas de infraestrutura e ter uma gestão apropriada às condições ambientais do local; melhorar a disponibilização de placas e roteiros e as condições de trafegabilidade de estradas e ramais. Isso desenvolverá os destinos turísticos, com seus recursos e produtos definidos e estruturados (principais, periféricos e complementares), o que influencia sua sustentabilidade e, por conseguinte, seu ciclo de vida, aliado a uma política de divulgação dos atrativos e de elaboração de negócios.

2)Pagamento por serviços ambientais prestados nas áreas naturais: assim, como no uso da imagem, a categoria APA e as reversas privadas também são excluídas do aproveitamento econômico dos serviços da região, o que não impede o desenvolvimento de mecanismos para proteger áreas naturais em propriedades privadas, a fim de inibir o avanço do desflorestamento, favorecer a recuperação de áreas degradadas, evitar a degradação dos recursos naturais e valorizar e ordenar os atrativos naturais/culturais.

3) Estudos de capacidade de carga e administração da visitação turística: um parque devidamente implementado tem todas as condições favoráveis para um controle maior sobre o fluxo da visitação e poder para contabilizá-lo, mas como esse procedimento será eficaz em uma APA onde predominam áreas privadas e direito de propriedade? A alternativa é envolver e convencer os proprietários a colaborar ou impor sanções com reedições da Instrução Normativa que regulamentem o uso público dos atrativos naturais, limite atividades poluidoras e registre o número de visitantes. Programas que visem ordenar o uso turístico são essenciais, principalmente se se basearem em estudos de carga/suporte e ferramentas para administrar os visitantes e suas preferências.

4) Melhorar o gerenciamento das áreas naturais: um amplo programa de uso público para essa APA deve oferecer condições aos atuais proprietários se inserirem em todas as fases de discussão e planejamento. Essa política deve ter três pilares básicos: (1) regulamentar o turismo nas áreas naturais, estabelecendo diretrizes e normas de conduta sujeitas a penalidades; (2) dotar 
as áreas com infraestrutura adequada às condições biofísicas, adequando e estudando a viabilidade paisagística de equipamentos ao ambiente, placas de localização, de sinalização interna, entre outros; e (3) capacitação profissional em áreas naturais para o turismo.

5)Envolver as comunidades no planejamento de turismo na APA: as comunidades têm interesse e motivação para atuar em projetos de uso público de áreas naturais e em ações de estruturação do turismo, mas precisam aproveitar suas expectativas e anseios para buscar soluções plausíveis, as quais deverão ser distribuídas nas comunidades e melhorar as condições de moradia, acesso, infraestrutura e oferta de atrativos para suprir a demanda turística.

Conclui-se que o envolvimento da comunidade é essencial na formulação e gestão dos projetos, pois estes podem solucionar outras demandas, como título de propriedade, qualificação profissional e orientação para o fomento, associativismo e empreendedorismo.

\section{REFERÊNCIAS}

Amazonas (2010, 28 de dezembro). Decreto no 30.873. Diário Oficial do Estado do Amazonas, Manaus, p. 2-4.

Amazonas (2010). Sistema Estadual de Unidades de Conservação (2ª ed.). Manaus: Secretaria de Estado do Meio Ambiente e Desenvolvimento Sustentável.

Amazonas (2012). Plano de gestão da Área de Proteção Ambiental (APA) Estadual Caverna do Maroaga. Manaus: CEUC-SDS.

Brandon, K. (1995). Etapas básicas para incentivar a participação local em projetos de turismo de natureza. In K. Lindberg \& D. E. Hawkins (Eds.). Ecoturismo: um guia para planejamento e gestão (L. C. M. Darin, trad., pp. 223-252). São Paulo: Senac São Paulo.

Brasil. Ministério do Turismo (2001). Diretrizes para o desenvolvimento do turismo rural no Brasil. Brasília: Mintur. Recuperado de http://www.turismo.gov.br/sites/default/ turismo/o_ministerio/publicacoes/downloads_publicacoes/Diretrizes_Desenvolvimento_ Turismo_Rural.pdf

Brasil (2008). Lei no 11.771, de 17 de setembro de 2008. Dispõe sobre a Política Nacional de Turismo e dá outras providências. Casa Civil, Presidência da República, Brasília.

Ferreira, C. A. \& Silva, H. D. (2008). O contexto florestal. In C. A. Ferreira. Formação de povoamento florestais (pp. 13-17). Colombo: Embrapa Florestas.

Fidalgo, E. C. C. (2003). Critérios para a análise de métodos e indicadores ambientais usados na etapa de diagnóstico de planejamentos ambientais. Tese de Doutorado, Faculdade de Engenharia Agrícola, Universidade Estadual de Campinas, Campinas.

Graziano da Silva, J., Vilarinho, C. \& Dale, P. J. (2000). Turismo em áreas rurais: suas possibilidades e limitações no Brasil. In J. A. Almeida, J. M. Froehlich \& M. Riedl. Turismo rural e desenvolvimento sustentável (pp. 15-62). Campinas: Papirus.

Gressler, L. A. (2004) Introdução à pesquisa: projetos e relatórios (2aㅡ ed.). São Paulo: Loyola. Instituto Brasileiro de Geografia e Estatística - IBGE (2007). Censo Agropecuário 2006: município de Presidente Figueiredo/estado do Amazonas. Rio de Janeiro: IBGE. Recuperado de: https://www.ibge.gov.br/estatisticas-novoportal/economicas/agricultura-epecuaria/9827-censo-agropecuario.html?=\&t=resultados 
Instituto de Proteção Ambiental do Estado do Amazonas - Ipam, Barros, J. F. (2005). Envolvimento e participação dos diferentes atores sociais no processo de elaboração do Plano de Manejo da "Área de Proteção Ambiental de Presidente Figueiredo Caverna do Maroaga" (Projeto Corredores Ecológicos, Relatório Final de Consultoria). Manaus: Ipaam.

Lima, M. L. C. (2003). (Eco)turismo em unidades de conservação. In A. B. Rodrigues (Org.). Ecoturismo no Brasil: possibilidades e limites do turismo (pp. 71-87). Contexto: São Paulo.

Marconi, M. A. \& Lakatos, E. M. (2016). Fundamentos de metodologia científica (7ํㅡㄹ.). São Paulo: Atlas.

Milano, M. S. (2000). Mitos no manejo de unidades de conservação no Brasil, ou a verdadeira ameaça. In Anais do II Congresso Brasileiro de Unidades de Conservação, 2000, Campo Grande. Curitiba: Rede Pró-Unidades de Conservação.

Mitja, D. \& Lescure, J. P. (2000). Madeira para perfume: qual será o destino do pau-rosa? In L. Emperaire. A floresta em jogo: o extrativismo na Amazônia Central (pp. 99-107). São Paulo: Editora UNESP, Imprensa Oficial do Estado de São Paulo.

Omena Júnior, R. \& Martins, C. S. (2007). Comportamento reprodutivo e caracterização de sítios de reprodução de galos-da-serra (Rupicola rupicola) no Amazonas. Revista Brasileira de Ornitologia, 15(1), 81-84. Recuperado de https://goo.gl/VGgwUb

Ribeiro, J. (2002). Ecoturismo: sustentabilidade na Amazônia. In A. Rivas \& C. E. C. Freitas (Orgs.). Amazônia: uma perspectiva interdisciplinar (pp. 253-271). Manaus: Editora da Universidade do Amazonas.

Rodrigues, A. B. (2000). Turismo eco-rural: interfaces entre o ecoturismo e o turismo rural. In J. A. Almeida, J. M. Froehlich \& M. Riedl. Turismo rural e desenvolvimento sustentável (pp. 111-126). Campinas: Papirus.

Scherl, L. M., Wilson, A., Wild, R., Blockhus, J., Franks, P., Mcneely, J. A., Mcshane, T. O. (2006). As áreas protegidas podem contribuir para a diminuição da pobreza? Oportunidades e Limitações. Gland: IUCN.

Spinola, C. A. (2006). 0 ecoturismo, o desenvolvimento local e a conservação da natureza em espaços naturais protegidos: objetivos conflitantes? RDE: Revista de Desenvolvimento Econômico, 13(8), 50-59. Recuperado de https://goo.gl/Lo5zcv

Yin, R. K. (2015). Estudo de caso: planejamento e métodos (C. M. Herrera, trad., 5aㅡ ed.). Porto Alegre: Bookman.

Recebido em: $31 / 5 / 2017$

Aprovado em: 18/10/2017

\section{CONTRIBUIÇÕES}

João Rodrigo Leitão dos Reis: definição do problema e dos objetivos de pesquisa; desenvolvimento da proposição teórica; realização da revisão bibliográfica e fundamentação teórica; escolha dos procedimentos metodológicos; coleta de dados; análise de dados; elaboração de tabelas, gráficos e figuras; redação do manuscrito; adequação do manuscrito às normas da RTA.

Julio César Rodríguez Tello: definição do problema dos objetivos de pesquisa; desenvolvimento da proposição teórica; realização da revisão bibliográfica e fundamentação teórica; escolha dos procedimentos metodológicos; análise de dados; revisão crítica do manuscrito.

Christina Fischer: realização da revisão bibliográfica e fundamentação teórica; escolha dos procedimentos metodológicos; análise de dados; revisão crítica do manuscrito; redação do manuscrito. 